\title{
Results of balloon and surgical valvuloplasty in congenital aortic valve stenosis: A 19-year, single-center, retrospective study
}

\author{
Doğumsal aort kapak darlığında balon ve cerrahi valvuloplasti sonuçları: 19 yıllık, \\ tek merkezli, retrospektif çalışma
}

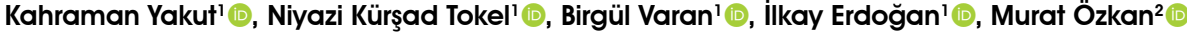 \\ 'Department of Child Health and Diseases, Division of Pediatric Cardiology, Başkent University Faculty of Medicine, Ankara, Turkey \\ ${ }^{2}$ Department of Cardiovascular Surgery, Başkent University Faculty of Medicine, Ankara, Turkey
}

\begin{abstract}
Background: This study aims to compare the success, complications, and long-term outcomes of aortic balloon valvuloplasty and surgical aortic valvuloplasty in pediatric patients with congenital aortic valve stenosis.
\end{abstract}

Methods: Between March 2000 and October 2019, a total of 267 procedures, including 238 balloon valvuloplasties and 29 surgical valvuloplasties, in 198 children (135 males, 63 females; mean age: $57.4 \pm 62.6$ months; range, 0.03 to 219 months) were retrospectively analyzed. The hospital records, echocardiographic images, catheterization data, angiography images, and operative data were reviewed.

Results: Aortic regurgitation was mild in 73 patients before balloon valvuloplasty, and none of the patients had moderate-to-severe aortic regurgitation. Compared to surgical valvuloplasty, the rate of increase in the aortic regurgitation after balloon valvuloplasty was significantly higher $(\mathrm{p}=0.012)$. The patients who underwent balloon valvuloplasty did not need reintervention for a mean period of $46 \pm 45.6$ months, whereas this period was significantly longer in those who underwent surgical valvuloplasty (mean $80.5 \pm 53.9$ months) $(\mathrm{p}=0.018)$. The overall failure rate was $8 \%$. Moderate-to-severe aortic regurgitation was the most important complication developing due to balloon valvuloplasty in the early period (13\%). All surgical valvuloplasties were successful. The mean length of hospitalization after balloon valvuloplasty was significantly shorter than surgical valvuloplasty ( $\mathrm{p}=0.026$ ). During follow-up, a total of 168 patients continued their follow-up, and a reinterventional or surgical intervention was not needed in 78 patients $(47 \%)$.

Conclusion: Aortic balloon valvuloplasty can be repeated safely and helps to eliminate aortic valve stenosis without needing sternotomy. Surgical valvuloplasty can be successfully performed in patients in whom the expected benefit from aortic balloon valvuloplasty is not achieved.

Keywords: Aortic balloon valvuloplasty, aortic valve stenosis, complication, surgical aortic valvuloplasty.
$\ddot{O} Z$

Amaç: Bu çalışmada, doğumsal aort kapak darlı̆̆ı olan çocuk hastalarda aort balon valvuloplasti ve cerrahi aort valvuloplastinin başarısı, komplikasyonları ve uzun dönem sonuçları karşılaştırıldı.

Çalışma planı: Mart 2000 - Ekim 2019 tarihleri arasında 198 çocukta (135 erkek, 63 kadın; ort yaş: $57.4 \pm 62.6$ yıl; dağ $11 ı$ m, 0.03 to 219 yıl) 238 'i balon valvuloplasti ve 29 'u cerrahi valvuloplasti olmak üzere toplam 267 işlem retrospektif olarak incelendi. Hastane kayıtları, ekokardiyografi görüntüleri, kateterizasyon verileri, anjiyografi görüntüleri ve ameliyat verileri değerlendirildi.

Bulgular: Balon valvuloplasti öncesi 73 hastada aort yetersizliği hafif düzeyde idi ve hastaların hiçbirinde orta ila şiddetli aort yetersizliği yoktu. Cerrahi valvuloplastiye kıyasla, balon valvuloplasti sonrası aort yetersizliğindeki artış oranı anlamlı düzeyde yüksekti $(\mathrm{p}=0.012)$. Balon valvuloplasti uygulanan hastalarda ortalama $46 \pm 45.6$ ay süreyle tekrar girişim gerekmez iken, bu süre cerrahi valvuloplasti uygulanan hastalarda anlamlı düzeyde daha uzundu (ortalama: $80.5 \pm 53.9$ ay) $(\mathrm{p}=0.018)$. Genel başarısızlık oranı \%8 idi. Orta ila şiddetli aort yetersizliği, balon valvuloplastiye bağlı erken dönemde görülen en önemli komplikasyon idi (\%13). Cerrahi valvuloplastilerin tümü başarılı idi. Balon valvuloplasti sonrasında ortalama hastanede kalış süresi, cerrahi valvuloplastiye kıyasla anlamlı düzeyde daha kısa idi $(\mathrm{p}=0.026)$. Takiplerine devam eden 168 hastanın 78'inde (\%47), tekrar girişimsel veya cerrahi müdahaleye gerek duyulmadı.

Sonuç: Aort balon valvuloplasti, güvenli bir şekilde tekrarlanabilir ve sternotomi ihtiyacı olmaksızın aort kapak darlığını ortadan kaldırabilir. Cerrahi valvuloplasti ise, aort balon valvuloplastiden beklenen yararın elde edilemediği hastalarda başarılı bir şekilde uygulanabilir.

Anahtar sözcükler: Aort balon valvuloplasti, aort kapak darlı̆̆ı, komplikasyon cerrahi aort valvuloplasti.

Received: August 02, 2020 Accepted: February 16, 2021 Published online: April 26, 2021

Correspondence: Kahraman Yakut, MD. Başkent Üniversitesi Tıp Fakültesi, Çocuk Sağlığı ve Hastalıkları Anabilim Dalı, Çocuk Kardiyoloji Bilim Dalı, 06490 Bahçelievler, Ankara, Türkiye. Tel: +90 312 - 2036868 e-mail: kahramanyakut@gmail.com 
Congenital aortic valve stenosis is a disease that requires lifelong monitoring with recurrent attempts. Aortic balloon valvuloplasty (ABV) and surgical aortic valvuloplasty (SAV) are among the treatment options. Numerous publications have reported that $\mathrm{ABV}$, applied as the first treatment option in many centers, facilitates a significant reduction in valve-level gradient and low frequency of recurrence in the short-term..$^{[1-5]}$ Similar to ABV, SAV provides an effective decrease in the valvelevel gradient. Low grade of aortic regurgitation and successful application in patients with ABV failure are important advantages of SAV, whereas prolonged hospitalization and cosmetic problems are the main disadvantages of SAV.

In some single-center studies, it was reported that SAV results were better and the rate of reintervention was low. ${ }^{[6,7]}$ Many studies have reported that the rate of recurrent attempts is higher after $\mathrm{ABV} .^{[2,8-10]}$ Although the first treatment option varies according to different centers, ABV was applied as the first option in our clinic because of its reproducibility. In the present study, we aimed to compare the efficacy, long-term outcomes, and complications of $\mathrm{ABV}$ and SAV in children with congenital aortic valve stenosis and identify the factors determining the choice of treatment in these children.

\section{PATIENTS AND METHODS}

This single-center, retrospective study was conducted at Başkent University Faculty of Medicine, Department of Pediatric Cardiology and Cardiovascular Surgery between March 2000 and October 2019. A total of 267 procedures, including $238 \mathrm{ABVs}$ and $29 \mathrm{SAVs}$, in 198 children (135 males, 63 females; mean age: $57.4 \pm 62.6$ months; range, 0.03 to 219 months) were reviewed. The patients with simple congenital heart disease (CHD) such as atrial septal defect, ventricular septal defect, patent ductus arteriosus, and aortic coarctation were included in the study. Patients with complex CHD were excluded, as such CHDs may affect prognosis. A written informed consent was obtained from each parent and/or legal guardians of the patient. The study protocol was approved by the Başkent University Faculty of Medicine Ethics Committee (KA20/111-17.03.2020). The study was conducted in accordance with the principles of the Declaration of Helsinki.

The ABV was preferred as the first treatment option in all patients. In the next procedure, SAV was preferred in patients in whom ABV failed or the initial valvuloplasty process did not achieve the expected level of improvement, as well as in those with dysplastic valves. Trivial aortic stenosis was defined as a transvalvular Doppler peak-systolic gradient less than $25 \mathrm{mmHg}$, mild stenosis as 25 to $49 \mathrm{mmHg}$, moderate stenosis as 50 to $75 \mathrm{mmHg}$, and severe stenosis as greater than $75 \mathrm{mmHg}{ }^{[11,12]}$ Both angiographic ${ }^{[13,14]}$ and echocardiographic ${ }^{[11]}$ examinations were used to classify the aortic regurgitation associated with the procedure. Aortic valve morphology was classified by echocardiography as monocuspid, bicuspid (functional or anatomic bicuspid), and tricuspid. Left ventricular systolic functions were classified according to ejection fraction and shortening fraction data. If the ejection fraction was below $30 \%$, left ventricular systolic function was considered to be severely impaired; if it was between 31 and 55\%, left ventricular systolic function was considered to be moderately impaired; and if it was above 55\%, left ventricular systolic function was considered to be normal. The diameter of the aortic annulus was measured by two-dimensional echocardiography and angiography in the left

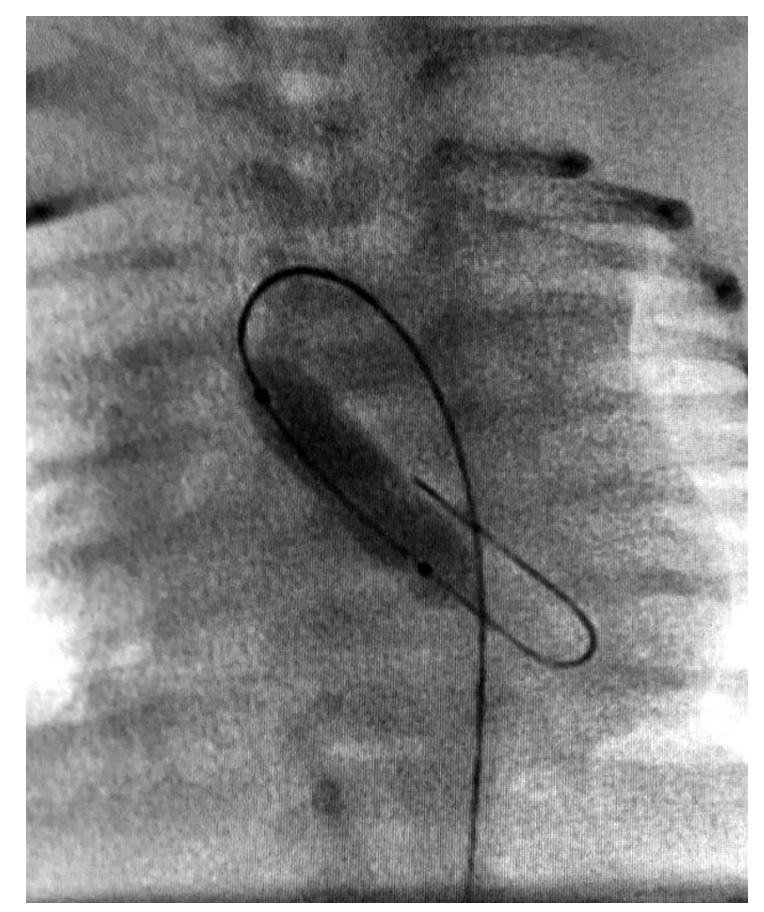

Figure 1. The angiogram of a five-day-old newborn with severe valvular aortic stenosis. Aortic annulus was measured as $6.4 \mathrm{~mm}$ in size. Balloon aortic valvuloplasty was performed using a 6-mm $(2 \mathrm{~cm}$ ) balloon (balloon diameter/annulus diameter: 0.94; Tyshak-II, NuMed Canada Inc., Cornwall, Canada). Peak systolic gradient in aortic valve decreased from $96 \mathrm{mmHg}$ to $24 \mathrm{mmHg}$. There was mild aortic regurgitation on aortogram after procedure. 
ventricular mid-systolic phase. The ABV procedure was started with balloons having a balloon diameter/ annulus diameter ratio of 0.75 to 0.9 . The procedure was continued with the balloon diameter/annulus diameter ratio of maximum 1 to 1.2, taking into account the residual transvalvular gradient and the grade of aortic regurgitation and, if necessary, increasing the balloon diameter by $1 \mathrm{~mm}$. Valvular aortic gradient was determined using echocardiography by measuring peak gradient and mean gradient with continuous flow Doppler. In addition, systolic valvular gradient was measured during catheterization. Cardiac catheterization was performed, when transthoracic echocardiography revealed a peak gradient of $\geq 50 \mathrm{mmHg}$ in the aortic valve, ST-T wave change in patients with peak gradient $<50 \mathrm{mmHg}$, presence of left ventricular systolic dysfunction, and/or decreased antegrade flow in the aortic valve. The success criteria for $\mathrm{ABV}$ and SAV was 40 to $50 \%$ reduction in the systolic pressure gradient (according to study period), a peak gradient of $<50 \mathrm{mmHg}$ in patients with normal cardiac output, decreased left ventricle end diastolic pressure, increased forward flow from the valve, and procedure-related moderate or less aortic regurgitation.

\section{SAV technique}

Midline split sternotomy was performed following induction of general anesthesia. Aortic and bicaval cannulation was preferred in every patient. Cold crystalloid cardioplegia was infused via an aortic root cannula to establish diastolic cardiac arrest. The right atrium was incised and cardioplegia was removed from the atria. In patients with moderate-to-severe aortic regurgitation, a left ventricular vent was placed through the right upper pulmonary vein after going on bypass, and cardioplegia was applied directly through the coronary ostium following a hockey stick style aortotomy. The identifiable commissures were incised all the way to the annulus to get a satisfactory aortic orifice. The raphe of an underdeveloped commissure was spared, but nodular fibrotic structures were excised and detached from the aortic wall for mobility. Thickened leaflets were shaved to increase mobility, as well. Subvalvular fibrotic membrane or fibromuscular thickening was resected, if necessary. The aortotomy was closed with fine polypropylene sutures.

\section{Statistical analysis}

Statistical analysis was performed using the IBM SPSS for Windows version 20.0 software (IBM Corp., Armonk, NY, USA). Descriptive data were presented in mean \pm standard deviation (SD), median (min-max) or number and percentage. The Kolmogorov-Smirnov test was used to evaluate the normality of quantitative variables. The comparison between groups of quantitative variables was performed with the independent samples t-test and Mann-Whitney U test. The chi-square test was used to assess the association between two qualitative variables. A binary logistic regression was applied to check multiple effects of independent variables on binary dependent variables. A two-tailed $p$ value of $<0.05$ was considered statistically significant.

\section{RESULTS}

The mean ages of the patients undergoing ABV and SAV were $55.2 \pm 64.9$ (range, 0.03 to 219) months and $66.6 \pm 48$ (range, 0.84 to 156 ) months, respectively, indicating no statistically significant difference $(p=0.542)$. The mean follow-up for all patients was $8.5 \pm 5.1$ years (range, 6 months to 18 years). The valve structure was bicuspid in 249 procedures, bicuspid and dysplastic in 10 procedures, tricuspid in two, and monocuspid and dysplastic in two. Aortic valve stenosis was critical in 25 of the interventions. Left ventricular systolic functions were normal in 233 of the procedures, impaired in 18 , and severely impaired in 12. Left ventricular functions returned to normal within six months after the intervention in all patients who underwent both ABV and SAV. In 50 of the procedures, there was endocardial fibroelastosis of the left ventricle. Twenty-five patients had aortic coarctation, one patient had discrete subaortic membrane, and one patient had supravalvular aortic stenosis. Twelve patients had severe heart failure symptoms before interventional procedures. In the acute period, no serious complications or death associated with ABV or SAV were observed (procedure-related complications within the first $24 \mathrm{~h}$ ).

\section{Results of ABV}

The ABV was repeated once in 198 patients, twice in 56 patients, and thrice in 10 patients. Approximately 123 of the interventions were implemented in children under the age of one year (Figure 1). The peak systolic gradient measured prior to $\mathrm{ABV}$ was $80 \pm 23.3$ (range, 35 to 182 ) $\mathrm{mmHg}$, which reduced to $38.7 \pm 17.9$ (range, 5 to 111 ) $\mathrm{mmHg}$ after the procedure. A significant decrease in the peak systolic gradient (mean: $41.5 \pm 21.1 \mathrm{mmHg}$ ) was achieved with ABV.

Nineteen of the ABV interventions were considered unsuccessful. Among all the intervention, six were considered unsuccessful, as the valve could not be passed through with guidewire, 12 failed as there was a significant residual gradient on the valve, and one was considered unsuccessful, as the patient developed severe aortic regurgitation due to valvuloplasty in 
the acute period. The mean balloon diameter/annulus diameter ratio selected for intervention was $0.96 \pm 0.1$ (range, 0.75 to 1.2). There was no statistically significant correlation between the final balloon diameter/annulus diameter ratio and the decrease in valve-level gradient $(\mathrm{p}=0.448)$. Similarly, there was no significant correlation between the increase in aortic regurgitation after the intervention and the final balloon diameter/annulus diameter ratio $(p=0.572)$. Aortic regurgitation was mild in 73 patients before $\mathrm{ABV}$, and none of the patients had moderate-tosevere aortic regurgitation. The ABV-related increase in aortic regurgitation was mild in 22 patients, moderate in 30 patients, and severe in one patient. A statistically significant increase was found in the ABV-related aortic regurgitation $(\mathrm{p}=0.006)$.

There was no need for reintervention for a mean period of $46 \pm 45.6$ (range, 0.01 to 180 ) months after ABV. Three patients developed dysrhythmia during the interventions. When supraventricular tachycardia ended with adenosine treatment in one patient, shortterm ventricular tachycardia attacks in two patients ended spontaneously without any intervention. The mean in-hospital follow-up after ABV was 1.7 \pm 0.9 (range, 1 to 5) days. The reasons for requiring intervention in patients requiring a reinterventional or surgical operation after the first intervention are shown in Table 1 and the interventions performed are presented in Table 2 .

Univariate and binary logistic regression analyses were performed in patients in terms of need for

Table 1. Reasons for intervention in patients requiring reintervention $(n=125)$

\begin{tabular}{lcc}
\hline Reason for reintervention & $\mathrm{n}$ & $\%$ \\
\hline Restenosis & 66 & 52.8 \\
Restenosis, AR & 17 & 13.6 \\
Restenosis, LVOTO & 3 & 2.4 \\
Restenosis, DSM & 2 & 1.6 \\
AR & 12 & 9.6 \\
AR, LVOTO & 5 & 4 \\
AR, DSM & 1 & 0.8 \\
AR, AAD & 1 & 0.8 \\
Failed ABV (high residual gradient) & 12 & 9.6 \\
Failed ABV (could not be passed through & 6 & 4.8 \\
the valve) & & \\
\hline
\end{tabular}

AR: Aortic regurgitation; LVOTO: Left ventricular outflow tract obstruction; DSM: Discrete subaortic membrane; AAD: Ascending aortic dilation. reintervention after the first interventional procedure. The univariate analysis (Table 3) showed that the younger the patient during the first intervention was, the higher is the risk of repeating intervention $(p=0.009)$. In the analysis of binary logistic regression using the same data, young age in ABV was not found to be a risk for repeated interventions (Table 4). None of the patients died in early and/or late period during follow-up.

\section{Results of SAV}

In 27 patients, SAV was performed once, but two SAV interventions were needed in one patient. The number of patients under the age of one who underwent SAV was nine. The mean peak systolic gradient with direct pressure measurement of left ventricle and aortic root before SAV was $93 \pm 12.6$ (range, 77 to 138 ) $\mathrm{mmHg}$, which decreased to $39.8 \pm 6$ (range, 24 to 48 ) $\mathrm{mmHg}$ after the procedure. The decrease in gradient varied between 38 and $93 \mathrm{mmHg}$ with a mean value of $53.1 \pm 10.7 \mathrm{mmHg}$. Aortic regurgitation increased slightly in 16 patients due

Table 2. Reinterventions in patients during follow-up $(n=133)$

\begin{tabular}{lcc}
\hline Reinterventions & $\mathrm{n}$ & $\%$ \\
\hline Re-ABV & 50 & 37.6 \\
Re-ReABV & 13 & 9.8 \\
SAV & 24 & 18.1 \\
Re-SAV & 1 & 0.8 \\
AVR & 24 & 18 \\
AVR, Konno procedure & 6 & 4.5 \\
Re-AVR, MVR & 2 & 1.5 \\
Ross procedure, PVR & 3 & 2.3 \\
SAV, DSM resection & 2 & 2.3 \\
AVR, DSM resection & 1 & 0.8 \\
Recurrent DSM resection & 1 & 0.8 \\
AVR, AREP & 1 & 0.8 \\
SAV, Enlargement of the ascending aorta & 1 & 0.8 \\
with patch & & \\
AVR, MVR & 1 & 0.8 \\
Bentall procedure & 1 & 0.8 \\
SAV, MVR & 1 & 0.8 \\
\hline
\end{tabular}

Note: Reinterventions in patients during follow-up are indicated in this table. In some patients, more than one intervention was performed.

ABV: Aortic balloon valvuloplasty; SAV: Surgical aortic valvuloplasty; AVR: Aortic valve replacement; MVR: Mitral valve replacement; PVR: Pulmonary valve replacement; DSM: Discrete subaortic membrane; AREP: Aortic root enlargement procedure. 


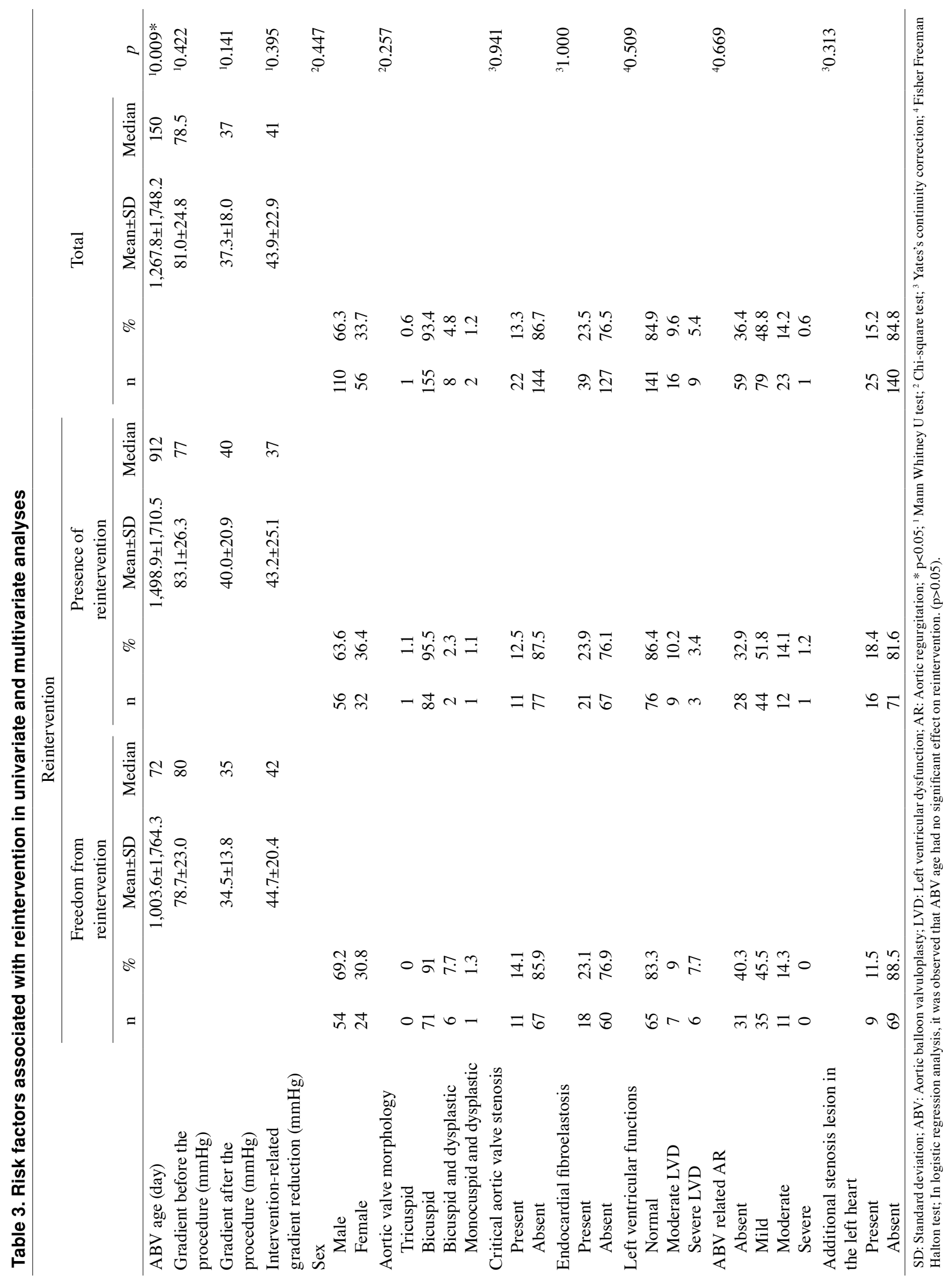


Table 4. Risk factors associated with reintervention by multivariate analysis

\begin{tabular}{lccc}
\hline & OR & \%95 CI & $p$ \\
\hline ABV age (day) & 1.000 & $1-1$ & 0.072 \\
Constant & 0.927 & & 0.695 \\
\hline
\end{tabular}

OR: Odds ratio; CI: Confidence interval; ABV: Aortic balloon valvuloplasty; In logistic regression analysis, it was observed that $\mathrm{ABV}$ age had no significant effect on reintervention. ( $p>0.05$ ).

to SAV, and there was no significant increase in the remaining 13 patients. All SAV operations were considered successful. There was no need for reintervention for a mean period of $80.5 \pm 53.9$ (range, 7 to 174) months after SAV. There was no significant correlation between the decrease in gradient and the increase in aortic regurgitation due to SAV $(\mathrm{p}=0.724)$. Two patients developed pericardial effusion, which recovered with nonsteroidal anti-inflammatory drugs. The mean length of hospitalization after SAV was $6.5 \pm 1.5$ (range, 5 to 10 ) days.

\section{Comparison of $\mathrm{ABV}$ and $\mathrm{SAV}$}

Compared to SAV, the rate of increase in aortic regurgitation after $\mathrm{ABV}$ was significantly higher $(\mathrm{p}=0.03)$. Another advantage of SAV over ABV was the longer duration of the period, when there was a need for reintervention. The patients who underwent ABV did not need reintervention for a mean period of $46 \pm 45.6$ (range, 0.01 to 180) months, whereas this period was significantly longer in those who underwent SAV (mean: 80.5 \pm 53.9 months). The duration of no need for reintervention after SAV was statistically significantly higher than the post-ABV period $(\mathrm{p}=0.008)$. Approximately 19 of transcatheter interventions failed, whereas SAV was successful in all patients. Compared to the patients who underwent $\mathrm{ABV}$, the length of hospitalization of the SAV patients was statistically significantly longer $(p=0.04)$. There was no significant difference between the peak systolic gradients measured on echocardiography prior to ABV, whereas the residual gradient measured after $A B V$ and that measured after SAV did not differ $(\mathrm{p}=0.243)$. Similarly, there was no significant difference between the decrease in gradient achieved with $\mathrm{ABV}$ and that achieved with SAV ( $\mathrm{p}=0.134)$.

\section{DISCUSSION}

The standard treatment approach for aortic valve stenosis was SAV until the first half of the 1980s. The ABV was, for the first time, was performed in 1984 by Lababidi et al. ${ }^{[15]}$ In subsequent studies,
$\mathrm{ABV}$ was reported as an alternative and effective method to SAV in all newborn and pediatric patients with congenital aortic valve stenosis..$^{[1,2,4,5,16-18]}$ For congenital aortic valve stenosis, a treatment method that eliminates stenosis without causing significant regurgitation in the valve is ideal. The first treatment option varies depending on the facilities of healthcare centers. In our study, the ABV was administered as the first treatment option owing to its repeatability. Patients with dysplastic or thick valves, where ABV was not beneficial enough, were treated with surgical treatment. Similar to the results of our study, SAV results were reported to be better as a result of improved surgical techniques in some single-center studies. ${ }^{[6,7]}$ As in our study, many recent studies have shown that the number of patients undergoing $A B V$ is much higher than the number of patients undergoing SAV. ${ }^{[6,8,17,19]}$

In a multi-center study, Hill et al. ${ }^{[8]}$ reported that the rate of reintervention was higher after ABV. Siddiqui et al. ${ }^{[7]}$ found a low rate of reintervention after SAV. In their multi-center study including 110 newborns, McCrindle et al. ${ }^{[17]}$ reported a significant difference between the rates of reintervention necessity after two treatment methods. ${ }^{[17]}$ In our study, the patients who underwent SAV were usually patients with dysplastic valves, and the duration of no need for reintervention after SAV was significantly longer in this group than in the $\mathrm{ABV}$ group.

It has been shown that the rate of repeated intervention in patients undergoing $\mathrm{ABV}$ as newborns and infants is higher. ${ }^{[2,9,10]}$ Similar to the literature, the results of the logistic regression analysis in our study revealed that $\mathrm{ABV}$ performed at young age did not carry a risk for reintervention, although interventions in newborns and infants were considered risk-enhancing factors for reinterventions, according to the univariate analysis.

Significant residual aortic stenosis after $A B V$ is one of the most challenging problems in dysplastic and thick aortic valves. The problem can be solved by continuing the procedure with a balloon of a larger size or by terminating the procedure and then performing SAV. In our experience in the clinical setting, we chose to terminate the procedure and, then, perform SAV, as we considered that continuing with larger balloon could increase the risk of developing aortic regurgitation, requiring the Ross procedure particularly in underage patients and more complicated interventions, such as aortic valve replacement along with mechanical aortic valve replacement and aortic root expansion in older children. 
Although the most common cause of reintervention in congenital aortic valve stenosis is the development of restenosis, ${ }^{[2,4]}$ the main factor determining the longterm prognosis is the iatrogenic aortic regurgitation developing after ABV or SAV. ${ }^{[2-4,16]}$ Maintaining valve functions plays a key role in the management of these patients. Although some studies have reported that the frequency of aortic regurgitation is similar after surgery and transcatheter treatment, ${ }^{[9,10,17,20,21]}$ others have shown that moderate-to-severe aortic regurgitation does not develop with $\mathrm{SAV}$, similar to our findings. ${ }^{[4]}$ In our study, restenosis was the most common cause of repeated interventions, consistent with the literature.

As reported in the literature, ${ }^{[7,9,19,22,23]}$ we found that the groups of $\mathrm{ABV}$ and SAV did not differ significantly in terms of their residual peak systolic gradients measured on post-treatment echocardiography. However, some other studies have shown that residual gradient is lower in patients undergoing $\mathrm{ABV} .^{[4,17]}$ Although there were few patients who underwent SAV in our study, the SAV results were favorable. In addition, the covers of patients who underwent SAV were dysplastic and did not benefit from ABV. We believe that, this is a reliable evidence to show that SAV is an effective intervention. The hospitalization in the intensive care unit and hospital after SAV is also significantly longer. ${ }^{[20]}$ Similarly, in the present study, the hospitalization after SAV was longer, (hospitalization after SAV: $6.5 \pm 1.5$ days vs. hospitalization after ABV: $1.7 \pm 0.9$ days).

The retrospective design of the present study is the main limitation in the collection and analysis of data. Changes in the surgical team performing the surgical procedures during 18 years may have also caused differences in patient selection and treatment strategy. However, all interventional procedures were performed by two pediatric cardiologists. During this period, there have been important changes and advances in balloon technology. The low number of patients who underwent SAV was another limitation. In this study, ABV and SAV procedures were applied sequentially to some patients and, therefore, it is not possible to clearly state whether the burden causing these patients to undergo aortic valve replacement (AVR) was ABV or SAV origin. Therefore, in this study, it was not considered a healthy data to indicate the AVR rate in patients who underwent ABV or SAV, which is an important limitation of the study. Further large-scale, prospective studies are needed to confirm these findings.
In conclusion, aortic balloon valvuloplasty can be repeated safely and helps to eliminate aortic valve stenosis without needing sternotomy. Surgical valvuloplasty can be successfully performed in patients in whom the expected benefit from aortic balloon valvuloplasty is not achieved, as there is no need for reintervention for a long period of time in surgical aortic valvuloplasty, which also has a rate of post-procedural residual gradient similar to that in aortic balloon valvuloplasty and a rate of aortic regurgitation development lower than that in aortic balloon valvuloplasty.

\section{Declaration of conflicting interests}

The authors declared no conflicts of interest with respect to the authorship and/or publication of this article.

\section{Funding}

The authors received no financial support for the research and/or authorship of this article.

\section{REFERENCES}

1. Torres A, Vincent JA, Everett A, Lim S, Foerster SR, Marshall AC, et al. Balloon valvuloplasty for congenital aortic stenosis: Multi-center safety and efficacy outcome assessment. Catheter Cardiovasc Interv 2015;86:808-20.

2. Sullivan PM, Rubio AE, Johnston TA, Jones TK. Longterm outcomes and reinterventions following balloon aortic valvuloplasty in pediatric patients with congenital aortic stenosis: A single-center study. Catheter Cardiovasc Interv 2017;89:288-96.

3. Soulatges C, Momeni M, Zarrouk N, Moniotte S, Carbonez $\mathrm{K}$, Barrea $\mathrm{C}$, et al. Long-term results of balloon valvuloplasty as primary treatment for congenital aortic valve stenosis: A 20-year review. Pediatr Cardiol 2015;36:1145-52.

4. Kallio M, Rahkonen O, Mattila I, Pihkala J. Congenital aortic stenosis: Treatment outcomes in a nationwide survey. Scand Cardiovasc J 2017;51:277-83.

5. Auld B, Carrigan L, Ward C, Justo R, Alphonso N, Anderson B. Balloon aortic valvuloplasty for congenital aortic stenosis: A 14-year single centre review. Heart Lung Circ 2019;28:632-6.

6. Brown JW, Rodefeld MD, Ruzmetov M, Eltayeb O, Yurdakok O, Turrentine MW. Surgical valvuloplasty versus balloon aortic dilation for congenital aortic stenosis: Are evidence-based outcomes relevant? Ann Thorac Surg 2012;94:146-53.

7. Siddiqui J, Brizard CP, Galati JC, Iyengar AJ, Hutchinson D, Konstantinov IE, et al. Surgical valvotomy and repair for neonatal and infant congenital aortic stenosis achieves better results than interventional catheterization. J Am Coll Cardiol 2013;62:2134-40.

8. Hill GD, Ginde S, Rios R, Frommelt PC, Hill KD. Surgical valvotomy versus balloon valvuloplasty for congenital aortic valve stenosis: A systematic review and meta-analysis. J Am Heart Assoc 2016;5:e003931. 
9. Brown DW, Dipilato AE, Chong EC, Lock JE, McElhinney DB. Aortic valve reinterventions after balloon aortic valvuloplasty for congenital aortic stenosis intermediate and late follow-up. J Am Coll Cardiol 2010;56:1740-9.

10. Ewert P, Bertram H, Breuer J, Dähnert I, Dittrich S, Eicken A, et al. Balloon valvuloplasty in the treatment of congenital aortic valve stenosis--a retrospective multicenter survey of more than 1000 patients. Int J Cardiol 2011;149:182-5.

11. Zoghbi WA, Enriquez-Sarano M, Foster E, Grayburn PA, Kraft CD, Levine RA, et al. Recommendations for evaluation of the severity of native valvular regurgitation with twodimensional and Doppler echocardiography. J Am Soc Echocardiog 2003;16:777-802.

12. Nishimura RA, Otto CM, Bonow RO, Carabello BA, Erwin JP 3rd, Fleisher LA, et al. 2017 AHA/ACC focused update of the 2014 AHA/ACC guideline for the management of patients with valvular heart disease: A report of the American College of Cardiology/American Heart Association Task Force on clinical practice guidelines. Circulation 2017;135:e1159-e1195.

13. Michel PL, Vahanian A, Besnainou F, Acar J. Value of qualitative angiographic grading in aortic regurgitation. Eur Heart J 1987;8 Suppl C:11-4.

14. Sellers RD, Levy MJ, Amplatz K, Lillehei CW. Left retrograde cardioangiography in acquired cardiac disease: Technic, indications and interpretations in 700 cases. Am J Cardiol 1964;14:437-47.

15. Lababidi Z, Wu JR, Walls JT. Percutaneous balloon aortic valvuloplasty: Results in 23 patients. Am J Cardiol 1984;53:194-7.

16. Maskatia SA, Justino H, Ing FF, Crystal MA, Mattamal RJ, Petit CJ. Aortic valve morphology is associated with outcomes following balloon valvuloplasty for congenital aortic stenosis. Catheter Cardiovasc Interv 2013;81:90-5.

17. McCrindle BW, Blackstone EH, Williams WG, Sittiwangkul R, Spray TL, Azakie A, et al. Are outcomes of surgical versus transcatheter balloon valvotomy equivalent in neonatal critical aortic stenosis? Circulation 2001;104(12 Suppl 1):I152-8.

18. Zain Z, Zadinello M, Menahem S, Brizard C. Neonatal isolated critical aortic valve stenosis: Balloon valvuloplasty or surgical valvotomy. Heart Lung Circ 2006;15:18-23.

19. Prijic SM, Vukomanovic VA, Stajevic MS, Bjelakovic BB, Zdravkovic MD, Sehic IN, et al. Balloon dilation and surgical valvotomy comparison in non-critical congenital aortic valve stenosis. Pediatr Cardiol 2015;36:616-24.

20. Justo RN, McCrindle BW, Benson LN, Williams WG, Freedom RM, Smallhorn JF. Aortic valve regurgitation after surgical versus percutaneous balloon valvotomy for congenital aortic valve stenosis. Am J Cardiol 1996;77:1332-8.

21. Fratz S, Gildein HP, Balling G, Sebening W, Genz T, Eicken A, et al. Aortic valvuloplasty in pediatric patients substantially postpones the need for aortic valve surgery: A single-center experience of 188 patients after up to 17.5 years of follow-up. Circulation 2008;117:1201-6.

22. Gatzoulis MA, Rigby ML, Shinebourne EA, Redington AN. Contemporary results of balloon valvuloplasty and surgical valvotomy for congenital aortic stenosis. Arch Dis Child 1995;73:66-9.

23. Atik SU, Eroğlu AG, Çinar B, Bakar MT, Saltik İL. Comparison of balloon dilatation and surgical valvuloplasty in non-critical congenital aortic valvular stenosis at longterm follow-up. Pediatr Cardiol 2018;39:1554-60. 